\title{
ELEMENTS OF SOURCING STRATEGIES IN FM SERVICES - A MULTIPLE CASE STUDY
}

\author{
Tomi VENTOVUORI \\ Real Estate Consulting, Pöyry Building Services Oy, P.O. Box 2, FI-02151 Espoo, Finland \\ E-mail: tomi.ventovuori@poyry.com; Tel. +358 40557 3391; Fax +358 94691311
}

Received 31 August 2006; accepted 20 November 2006

\begin{abstract}
The aim of this paper is to identify the different elements of the sourcing strategy decision-making process and to clarify what are the factors that lead to the selection of a certain sourcing strategy in FM services. The study is based on a literature review and a multiple case study, which was conducted with four organizations representing different types of FM service clients. To find the optimal sourcing strategy and understand the consequences of different sourcing options, five decision categories must be analysed: sourcing interface, organizational decision-making, the scope of service package, the geographical area of sourcing and relationship type. There are also some other elements that must be taken into account in the process of sourcing strategy development such as different elements of business in general and the prevailing market conditions. It is strongly suggested that companies could apply the presented integrated approach as a starting point for the development of sourcing strategies in FM services. In addition, this study shows that companies should view the development of sourcing strategies as an important phase of the procurement cycle.
\end{abstract}

KEYWORDS: Sourcing strategy; Strategic planning; Facilities management services; Multiple case study

\section{INTRODUCTION}

Strategic planning of sourcing is gaining increasing attention in supply management practice and in academic research. As in other areas of supply management, a transition seems to be going on in the way companies plan and reorganize their purchases in facilities management (FM) services. While clients are changing the job description of in-house FM staff from routine purchasing tasks to more strategic tasks that support the overall goals of the company (cf. Kadefors and Bröchner 2004), they are also trying to trim their supply bases in many ways. For example, while some companies are entering into closer rela- tionships with their remaining suppliers (Incognito 2002), others are shifting from using a sole supplier to using a number of specialist partners (Usher 2004). This, among other reasons, is why the FM practitioners need to be more familiar with the expanding range of sourcing options (Smith et al. 2004).

It is also commonly suggested that effective procurement planning and management of FM services can directly affect the relative success or partial failure of an organization's business (e.g. Leifer 2003; Chotipanich 2004; Rogers 2004). The general lack of sourcing strategies revealed in the examination of FM practices, supports the fact that the outsourcing and procurement practices of FM

International Journal of Strategic Property Management 
services are still in a transformation phase (Lehtonen and Salonen, 2006). Thus, it is surprising that only few studies carried out have focused on the development and implementation of sourcing strategies (Bröchner et al. 2004, Hui and Tsang 2004, Ancarani and Capaldo 2005) or the essential elements of them, such as outsourcing decisions (Usher 2004), service bundling (Barret and Baldry, 2003; Ancarani et al. 2004) and the selection of relationship type (Lehtonen, 2006). However, these studies have focused only on partial elements of sourcing strategies mostly without any efforts toward integration. They failed in recognising a relation between each other and also the consequences of such decisions. The lack of conceptual and theoretical frameworks is perhaps one reason why strategic planning of sourcing is ignored in the field of FM (Then, 2000; Koskela, 2005).

The scale of the recent changes in the FM services practice is so considerable that an analysis of sourcing strategies is of interest. In this study, besides reviewing the literature on sourcing strategy approaches and creating a theoretical framework for the development of sourcing strategies in FM services, we present real-life examples, which came up during the multiple case study. The framework is used to examine the realized sourcing strategies in the case companies. The case study was conducted to identify the elements of the sourcing strategy decision-making process and to clarify what are the factors that lead to selecting a certain sourcing strategy in FM services in practice. It is also of interest to know how the supply base can be structured.

\section{A REVIEW OF SOURCING STRATEGY APPROACHES}

In deciding on a sourcing strategy for particular segments of business, management has a wide range of options. The most common sourcing strategy approach deals with make or buy decisions. According to this approach, the company must make a choice between two strategic approaches: whether to concentrate its own resources on a set of core competencies or produce support functions in-house (Snyder and Ebeling, 1992, Venkatesan 1992, Barney 1995). Focusing on core competences and leveraging sourced relationships against each other enables the achievement of economies of scale, thus making it possible to provide goods and services more efficiently while improving quality through the application of specialist knowledge (Quinn and Hilmer, 1994).

Some sourcing strategies concentrate on supply base structuring. According to several authors, once make or buy analyses are carried out in favour of buy, the company is involved in such strategic decisions regarding supply base structuring (e.g. Gadde and Håkansson, 1994; Hines, 1995; de Boer et al., 1998). Supply base structuring can be seen as having two strategic aspects (Gadde and Håkansson, 1994): one has to do with the way of suppliers are organised and the other with the number of suppliers to use.

The supply base can be organised structurally in various ways. Structurally, the buying company is at the centre of all service providers in the supply base, coordinating and controlling its activities (Bröchner et al., 2004). The buying company may induce working relationships among service providers (Incognito, 2002; Lehtonen, 2004), while some self-governing relationships may form among the service providers (Meneghetti and Chinese, 2002). In the supply base, not all suppliers are directly connected to the buying company. The supply base may take form of a supply network when it is constructed in the form of a hierarchical pyramid with second- and third tiered suppliers (Hines, 1995). Depending on the buying company's sourcing strategies, the supply base may include suppliers in second and third tiers (Choi and Hong, 2002).

If a company has business relationships with a number of suppliers, it is engaged in what is called multiple sourcing. In this classical approach, each of the suppliers responds to the demands and specifications defined for 
a particular price, and competition is often given priority (Zeng, 2000). By promoting competition among the suppliers, the client is expected to be given better control of price levels (Gadde and Håkansson, 1994). Competition should also alleviate the uncertainty of relying on one supplier (Min and Galle, 1991). On the contrary, single sourcing involves the idea of reducing the number of suppliers a company does business with (Zeng, 2000). When buying FM services, the number of service providers can be reduced either by bundling different services together or by grouping sites under one contract. Cox (1996) defines that in single sourcing, the buying company decides to have a single relationship with one preferred supplier, who is granted a relatively permanent preferential relationship including a variety of tasks. Single sourcing implies that a number of alternative suppliers is available in the market, but the buyer selects and uses only one supplier (Newman, 1988). When only one supplier is available and the buyer uses that supplier, the circumstance is called sole sourcing. According to Quayle (1998) sole sourcing is the result of the client being forced to buy from one supplier only as a result of such market factors as location, exclusive design rights, a particular customer specification and possible buyer inertia.

Some sourcing strategic choices deal with the forms of the different buyer-supplier relationships (e.g. Webster 1992; Mentzer et al. 2000, Cousins 2002) and the duration of contracts (e.g. Ramsay and Wilson, 1990; Parker and Hartley 1997). Guidelines for selecting relationship type usually only identify partnership sourcing and competition as discrete categories (e.g. Macbeth 1994). However, even casual observation of actual supply relationships reveals that there are different forms of partnership sourcing and different forms of competition (e.g. very short-term contracting and long-term contracting) (Parker and Hartley 1997). Arm's length relationships are usually described as short-term relations based on a competitive bidding (Mentzer et al. 2000).
Whereas the short-term contracts create a very low level of contractual liability in the relationships, the use of long-term contracts develops closer relationships with selected suppliers and brings increased liabilities into relationships (Ramsay and Wilson, 1990). Partnership sourcing can be divided into the operational and strategic forms. Operational partnering refers to working with few suppliers and focusing mainly on uncertainty reduction and process improvements such as improvements in quality (Mentzer et al. 2000, Cousins 2002). Strategic partnering is defined as an ongoing, long-term inter-organizational relationship for achieving competitive strategic goals. If the partner goes out of business, a firm would have to change its competitive strategy (Johnson, 1999).

Atkin and Brooks (2005) have also considered the structure of the sourcing organization as an important element in developing a sourcing strategy. The buying company can use in-house sourcing or it can also use an external organisation ("managing company") that purchases and manages the service providers on behalf of the buying company. Structurally, there are basically four different contractual and management arrangements in the providing of FM services. The first is that the buying company can pass the full responsibility for managing and providing a whole range of bundled services to a single organisation (total facilities management). The second involves the employment of a managing agent that is responsible for arranging the service provider base on behalf of the buying company. In this case, the agent makes the contracts directly on behalf of the buying company. The third arrangement involves a managing contractor, and differs from the former in the way that in this arrangement the service providers make a contract with the managing contractor, and do not have a contractual relationship with the buying company. The fourth arrangement is the managed budget. This approach is similar to the managing contractor model but differences lie in the sharing of risk and in the earn- 
ing principles. In the managed budget model, the management fee is based on the value of budgeted expenditures. All subcontract invoices and contract specific employee costs are processed without any mark-up. Where as the managing contractor takes responsibility for the payment of all suppliers and adds the mark-up to the invoice.

The other important aspect of the structure of the procurement organization is the degree of centralization (Smeltzer, 1997). Centralization refers to the structure in which authority and decision making are focused around one individual or a small group. When authority and the power to make decisions are distributed between many individuals at different levels within the organisation, the structure is decentralized. Krumm and associates (1998) have discovered that central coordination of the procurement of products and services may result in economies of scale and the creation of negotiating advantages. Instead of developing individual contracts, a centralized unit is able to purchase large quantities and offer the prospect of future purchases for the supplier.

\section{SUPPLY ENVIRONMENT}

The sourcing strategy formulation process often includes an analysis of the external environment and an assessment of the internal factors of the organization (Pearson and Gritzmacher, 1990; Carr and Smeltzer, 1997; Hatch, 1997; Virolainen, 1998). To help in building the strategy, an organisation must make a forecast about the environmental conditions that will be encountered in the future to achieve its goals and procurement should know the suppliers' environments that affect corporate goals (Carr and Smeltzer, 1997). Therefore, procurement cannot operate in isolation from its environment, including the supply market and other elements of business. The optimal supply base may be sensitive to changes in the market environment because complex systems, such as supply networks, are embedded in the environment and interact with the base (Choi et al., 2001). Thus, it is recommended that sourcing strategies should also include analysis of the markets from which key products and services may be sourced (Farmer and van Weele, 1995).

When analysing supply markets and matching external resources provided by suppliers with the internal needs of the buying company, purchasing portfolio models are nowadays widely used. For example, some of those models can be used to analyze the company's purchases to ascertain the ideal relationship types for different purchases (Olsen and Ellram, 1997; Bensaou, 1999) and others can be used to analyze the company's own strength against the supplier market (Kraljic, 1983). A real problem can occur when the supplier's priorities do not match the buyer's. Lack of knowledge in a limited supply market may cause difficulty in making purchasing decisions, especially in cases in which only a few suppliers are capable of providing a particular good or service that meets the required standards, has the appropriate volume, or is situated in the required geographical location. Any of these restrictions opens up the possibility for the supplier to exploit the situation (Lonsdale, 1999).

\section{METHODOLOGY}

This study began with the evaluation of sourcing strategy approaches in the literature. Based on the literature and the author's own interpretation of it a theoretical framework was developed. The framework was used to examine the realized sourcing strategies in the case oragnizations and to support the analysis of empirical data. The objective of the empirical part was not to test the developed framework but rather to study further and seek more understanding of the phenomena explored. As sourcing strategies may vary greatly from one purchasing situation to another (Corey, 1978) and a certain sourcing strategy in one business environment may not be as successful when transplanted elsewhere (Virolainen, 
1998), it was necessary to seek a deeper understanding of the subject under exploration through an empirical study.

The empirical study was carried out as a multiple case study. The case study was conducted with four organizations representing different types of FM service clients and aimed to map the process of developing a sourcing strategy for the procurement of FM services and to analyze the elements of this decisionmaking process. This approach was chosen because case research is a useful strategy for studying processes in companies (Gummesson, 1991) and it enables an intensive analysis of a particular phenomenon in quite a small number of business units (Eisenhart, 1989). All the four participating companies are major players in the Finnish FM service market and they participated in this project as corporate research partners.

According to Woodside and Wilson (2003), multiple sources are needed to gain a more comprehensive understanding of the same event. The data of each case was collected in five main phases using open-ended questionnaires as well as semi-structured and focus group interviews (Table 1). In the first phase, semi-structured interviews were conducted at the strategic level of the case organizations. The strategic level was chosen because people at this level are assumed to have the best knowledge of the business environment. In the second phase, the open-ended questionnaire was sent to persons of the case organizations who were responsible for sourcing and managing FM services. The questionnaire consisted of questions related to the current state of sourcing practices. In the third and fifth phase, data was collected using focus group interviews. The interviews were conducted at the managerial level in two separate sessions, involving two to five experienced real estate professionals. The focus group interviews were comprised of questions concerning the elements of decision-making processes of developing sourcing strategies. In addition, between sessions in phase four, another open-ended questionnaire was sent to the participants of focus groups. This was concerned with the strategic objectives of procurement management.

Characteristic of the phased data collection described above was that each phase ended in written output and after more detailed coding, the data was transferred as an input into the next data collection phase. Through the data collection, altogether 18 higher-level managers (i.e. those working at the strategic and tactical level of the organization) were interviewed in 12 interviews and a total of 16 responses were rendered in openended questionnaires.

Table 1. Conducted data collections

\begin{tabular}{|c|c|c|c|c|c|c|}
\hline \multirow{2}{*}{$\begin{array}{l}\text { Data collection } \\
\text { phase }\end{array}$} & \multirow{2}{*}{$\begin{array}{l}\text { Data collection } \\
\text { method }\end{array}$} & \multirow[t]{2}{*}{ Purpose of the phase } & \multicolumn{4}{|c|}{ Number of informants } \\
\hline & & & Case 1 & Case 2 & Case 3 & Case 4 \\
\hline 1 & $\begin{array}{l}\text { Semi-structured } \\
\text { interview }\end{array}$ & $\begin{array}{l}\text { Understanding of business } \\
\text { environment }\end{array}$ & 2 & 3 & 1 & 1 \\
\hline 2 & $\begin{array}{l}\text { Open-ended } \\
\text { questionnaire }\end{array}$ & $\begin{array}{l}\text { Understanding current state of } \\
\text { sourcing practices }\end{array}$ & 2 & 1 & 1 & 1 \\
\hline 3 & $\begin{array}{l}\text { Focus group } \\
\text { interview }\end{array}$ & $\begin{array}{l}\text { Analysis of sourcing decision- } \\
\text { making }\end{array}$ & 2 & 5 & 3 & 3 \\
\hline 4 & $\begin{array}{l}\text { Open-ended } \\
\text { questionnaire }\end{array}$ & $\begin{array}{l}\text { Defining strategic } \\
\text { objectives of sourcing }\end{array}$ & 3 & 4 & 1 & 3 \\
\hline 5 & $\begin{array}{l}\text { Focus group } \\
\text { interview }\end{array}$ & $\begin{array}{l}\text { Analysis of sourcing decision- } \\
\text { making }\end{array}$ & 2 & 4 & 2 & 3 \\
\hline
\end{tabular}




\section{FRAMEWORK FOR SOURCING STRATEGY DEVELOPMENT IN FM SERVICES}

The framework suggested in this study results from a study of various approaches discussed in the literature. In the strategy proposed in this paper we understand sourcing strategy in FM services as a mix of different strategic decisions (Figure 1). The client must make a decision in five different categories when developing a sourcing strategy. There are also some other elements that must be taken into account in the process of sourcing strategy development such as different elements of business in general and the prevailing market conditions.

The main principle in the framework is that procurement cannot operate in isolation from its environment and other elements of business (see Figure 1, outer boxes with dashed lines). Other important principles are that sourcing objectives and decisions that affect the company's overall performance need to be consistent with business strategy and the company's service providers have to have the capability to meet its strategic priorities.
The inner boxes with solid lines in the framework represent the client's internal elements of sourcing strategy decisions in five categories. The first two categories include strategic decisions in relation to the structure of the sourcing organization and the last three categories include decisions that influence the structure of the service provider base in reference to the number of service providers and the selection among different relationship types. Each of these categories of sourcing decisions has at least two decision choices. To find the optimal sourcing strategy and understand the consequences of each decision, each of the five categories must be considered. There are also market-specific factors that may influence decision-making on how to form the sourcing strategy and structure the company's service provider base.

In the first category, the client must explicitly consider the implications of an organisation's choice between producing services inhouse or using external service providers in order to fulfil the FM service demand. Besides these options, the organisation in question may consider executing sourcing internally or possibly use an external sourcing organisation that

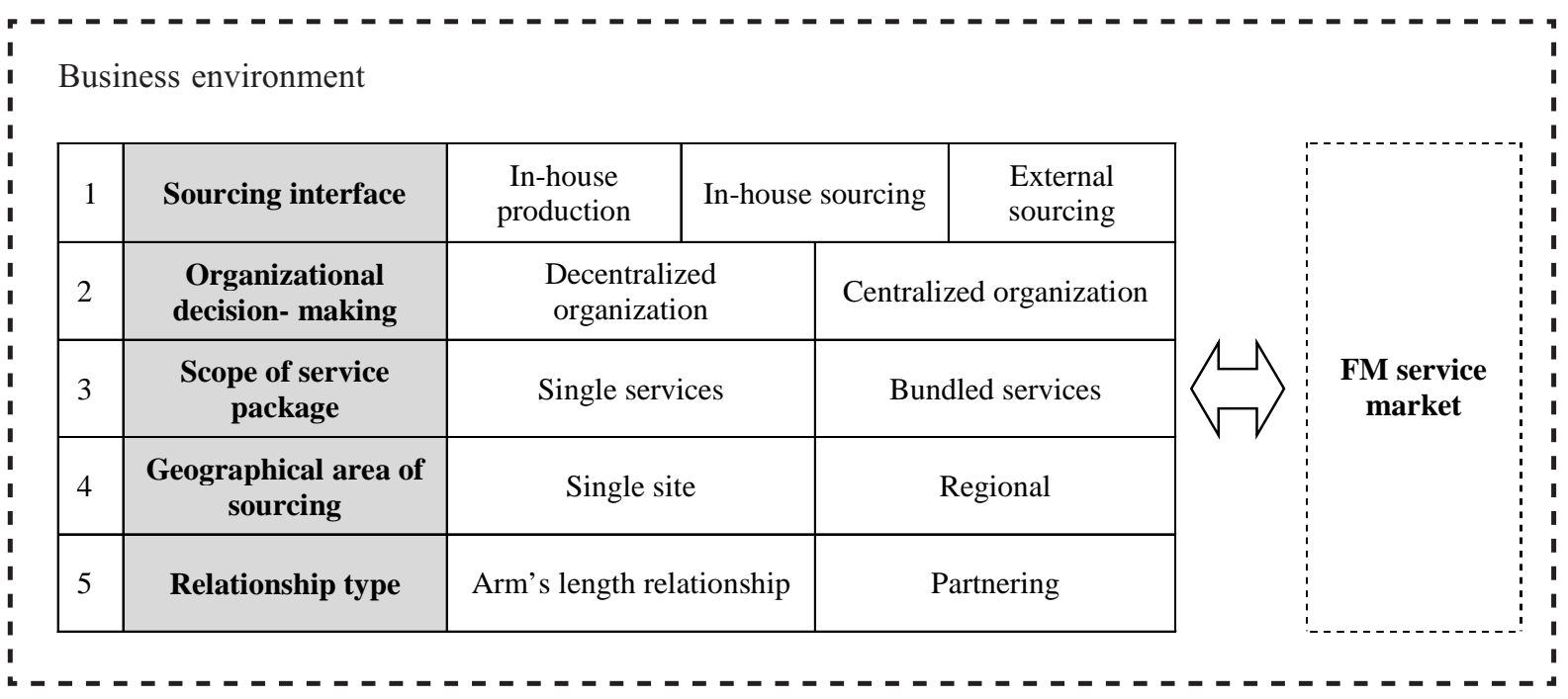

Figure 1. An integrated approach to the development of sourcing strategy in FM services 
purchases services and manages the service provider base on behalf of the client, often called a managing company. The second category that affects the organisation of sourcing and how the service provider base can be managed is the degree of centralization including the choice between decentralized and centralized organisation. There may be in-house sourcing unit or external sourcing organisation that are managed and coordinated in a decentralized manner through many individuals around the organization. Organizational decision-making may also take the form in which authority and decision making are focused around one individual or a central function of organisation.

The third and the fourth category affect the structure of the service provider base in reference to the number of service providers to use. When sourcing FM services, the number of service providers can be reduced either by bundling different services together or by grouping sites under one contract. The third category includes decisions that concern the scope of service packages in reference to buying single services by a number of service contracts or bundling of them into one contract. Service bundling is closely linked with the decisions concerning the defining of the geographical area of sourcing that is the fourth category in the framework. In the fourth category, the buying company must consider whether to buy an individual service or a bundle of services by the same contract for a single site or a certain region (i.e. multiple sites). A site here means a single building or a complex of adjacent buildings. The fifth category defines the selection of relationship type between an arm's length relationship and partnership sourcing. The result of the choice made in this category is that the buying company has decided what kind of collaboration it ought to pursue.

Together, all the presented decisions categories must be evaluated against the market conditions at least for the following factors: number of available service providers, availability of different services and the size of service organizations.

\section{A MULTIPLE CASE STUDY}

The multiple case study was conducted with four companies divided into four types of property owner: (Case 1) city (user-owner organization), (Case 2) broadcasting company (userowner company), (Case 3) institutional mutual pension insurance fund (real estate investor company) and (Case 4) non-listed property investment company in residential market (real estate investor company). Each of the case organizations represents different sourcing environments in different sectors of the property market. These cases are numbered Case 1 Case 4 throughout the paper in order to maintain anonymity. While the all studied case organizations lacked written forms of sourcing strategies, the essential elements of sourcing strategies were identified by using the theoretical framework developed.

\section{Case 1: City}

One of the case study organizations operates in the public sector. Of all the other cases, this organization has the smallest geographical spread of properties. All of its properties amount to 2.5 million square meters and are located in the area of one city. Offices, schools and specialised property holdings such as hospital buildings dominate the organization's portfolio. Eighty percent of its properties are rented internally to the different departments of the city. The service provider base consists of one internal service organization and dozens of external local service providers. The objectives of the company in the procurement and supply management of FM services include: maintaining the value of properties at an appropriate level and supporting the users of the premises, improving effectiveness of procurement decision making, rationalizing service provider base by grouping sites and decreasing the frequency of bidding by developing partnering relations.

To improve the effectiveness of procurement decision-making, the case organization is re- 
organizing the procurement functions to make them more centralized. The main reason identified for centralization was preparation for retirement of in-house staff and decreasing financial resources in the upcoming years. The centralized model allows the case organization to concentrate its scarce future resources on a set of more important activities that support the overall goals of the organization. In addition, this allows for decisions to be made more effectively, for two reasons. Firstly, buying procedures will become more similar to each other. Secondly, direct access to comparable cost and quality data from all sites will simplify the tasks of service provider monitoring and evaluation of providers against each other.

In order to manage the service provider base with a small centralized unit, the organization is preparing to rationalize the service provider base by grouping sites regionally but avoiding service bundling. The case organization has avoided service bundling for several reasons. By bundling service purchases, the procurement organizations become more dependent on one service provider and the changing of the large service provider may be time consuming. In addition, the service provider may not have the capabilities and competences for providing all bundled services in the way required. The buying organization may have to rely on the skills and specialized knowledge of the subcontractors (i.e. second tier service providers). When relying on an increased number of tiered service providers, the probability of undelivered services may be increased because it is difficult for the buying organization to control a large number of tiered service providers.

Instead of buying an individual service for a single site in the future, the organization has planned to rationalize its service provider base by extending service contracts to cover a large number of office buildings in six different regions of the city. The main reason identified for grouping sites on a region basis was that there are no service providers in the market that can provide the required services for all the sites in a large real estate portfolio. The benefit of bundling is that the number of transactions decreases and as a consequence there is less bureaucracy in decision-making. On the other hand, when rationalizing the service provider base by extending service contracts to cover large numbers of buildings, the procurement and management tasks may become very complex, especially in the case of grouping technically demanding sites. Thus, in a case of buying services for the specialized properties, site specific contracts have been made. An example of such a site is a hospital building where failures in service provision could have dramatic negative consequences on the operations of the users of the premises.

\section{Case 2: Broadcasting Company}

The second case analysed was a broadcasting company that holds premises for the use of its own employees. The company's portfolio is dominated by offices, which are located in cities and close to cities and amount to 280 thousand square meters. A network of 690 service providers provides FM services to its sites nation wide. The objectives of the company in procurement and supply management of FM services include: rationalizing service provider base by decreasing number of service providers, moving from an adversarial to a collaborative relationship approach and creating systematic and cohesive sourcing procedures among the buyers.

In the case organization, eight individuals in a centralized unit are nowadays involved in sourcing decisions. Earlier experience of decentralizing the sourcing procedures has been the fragmentation of procedures around the company with many local service contracts set up to buy the same services, often unknowingly bought from the same service provider. In spite of the centralized structure, the company has been mitigating fragmented sourcing procedures. It was found that centralized decisions help the company to monitor the service providers, follow key expenditures and measure 
internal sourcing performance. In addition, in centralized structure there are the cost and discount incentives of doing larger deals. It also allows the case company to focus on more important activities.

The company is objectively decreasing its wide service provider base by bundling different services and grouping sites to one supplier. Once the service provider base is reduced, the number of transactions among the service providers is also reduced, which makes it easier for the case company to coordinate its service provider base with less in-house resources. It was also found that service performance indicators such as costs and quality are easier to monitor when using a smaller number of service providers, and thus the cost of monitoring is also reduced. In addition, the cost benefits are achieved when the service processes are planned in such a way that one person can do different service tasks in one site or even several sites. Once they bundled services into one contract, service providers were also more willing to do tasks, which they do not typically do. This was done in the cases where service provision did not require a high level of technical expertises. It was also argued that if services are bundled into overly wide packages it becomes impossible to find enough service providers in the market that can provide also all technical services included in the service package.

As most of the company's sites in the real estate portfolio are physically far away from other sites, the company mainly buys a bundle of services by the same contract on a single sits basis. However, it has planned to extend service contracts to cover a large number of office buildings. The primary way of grouping sites to one service provider is to group them regionally to one service provider instead of grouping sites from all over the country to one service provider. It was thought that grouping sites regionally makes the purchased package still attractive and large enough for developing partnering relations. It was identified that the risk of grouping sites to one service provider nation wide is that when there is no comparable market information for benchmarking service levels and cost between the regions, the one service provider can raise the prices over market level. To get market information, the case company has to repeatedly and often put the services out to tender, which has raised transaction costs. However, it was stated that due to continuous bidding there is no time to develop the partnership relations but only use arm's length relationships with selected service providers.

\section{Case 3: Institutional Mutual Pension Insurance Fund}

The third of the case studies was carried out in the department of real estate investments in a large institutional mutual pension insurance fund, which owns private equity in the form of altogether more than 200 commercial properties and over 5,000 apartments. It owns properties all over the nation and these are widely spread geographically. Measured in area they amount to 1.3 million square metres. The service provider base consists from a dozen of large service organizations. It is also important to note that each service organization in the service market is also a potential customer of pension insurance. The objectives of the company in procurement and supply management of FM services include: improving or maintaining the productivity of properties and the value of properties at an appropriate level, increasing affectivity of decisions by authorizing sourcing decisions to the central management, rationalizing service provider base by pruning inefficient providers and developing long term relationships with preferred service providers.

The company has authorized the central unit to with the three individuals to make sourcing decisions and has outsourced the management of service contracts to an external managing company. The service contracts are directly made on behalf of the case company. According to company data, the manag- 
ing company is considered as a strategic partner. Besides the company managing the service contracts, it has wide-range responsibility for managing the client's customer (i.e. tenant) relations. It was stated that this applied external sourcing model allows the organizations to concentrate its scarce resources on a set of real estate investment activities and to focus on more strategic procurement tasks including strategic planning and steering the activities of the supply network towards the overall goals of the company. In addition, it was stated that the small number of individuals in the central unit makes the case company flexible and capable to react rapidly to changes in the real estate portfolio. The centralized model also helps to realize economies of scale since it involves bundling services together or grouping sites under one contract. It was also found that a broader service package with the promise of a long-term contract has generated negotiation advantages for the case company, which in turn has made the relationship more attractive from the service provider's perspective.

During the centralization and outsourcing of the management of service contracts, the case company has rationalized the supply base by splitting purchased services between 16 large preferred service providers in the way that two to four different providers are responsible for a particular service area (i.e. 4 for real estate maintenance, 4 for grounds maintenance, 4 for cleaning, 2 for technical maintenance and 2 for waste management). According to company data, each preferred service provider is considered an operational partner. The case company also purchases services from the small service providers if the preferred service providers cannot offer a needed service for a certain site or regions at a reasonable price and with reasonable quality. The basic philosophy behind the forming of a preferred service provider structure is the aim to have access to the best available skills and expertise in the particular service area. On the other hand, splitting the services among multiple limited service providers reduces the supply risk for the service area. The supply risk was understood as the risk of the service provider no being capable of meeting the client's or endusers' requirements for a competitive price, which can result in the loss of the company business and negatively affect revenues and profits of the case company. It was also seen that by working with a limited number of preferred service providers for consolidated purchases, the case company can be more effective in communicating its needs and can better induce the service providers to be more responsive to its immediate needs.

Besides splitting purchased services, the case company has formed wide service packages in each selected service area by grouping sites under regional contracts. However, it was stated that if the sites are grouped under nation-wide contracts or services are purchased on a single site basis, the company is not able to gain maximum benefits through economies of scale. Synergy was not created if the service provider is unable to reach the number of sites from one location. It was found that cost advantages are created if the sites are located close to each other. In this favourable situation, the service provider can convert savings into lower prices, higher service levels or the creation of innovative structures and procedures. In addition, the cost advantages associated with the cost of coordination are lost if the service provider is obligated to use second and third tier service providers in a certain area. The number of tiered service providers in the same region increases the probability of unreliable service delivery at the sites, because it is difficult to control all tiered service providers cost-effectively. In addition, it was found that when the purchased services are grouped into larger packages in the compact regions, this creates a good starting point for engaging service providers in long-term relationships and establishing partnering relations with them. However, it is important to note that as most employers of the service providers are also customers of pension insurance, the case company has been willing to commit all of its service providers to long term relationship. 


\section{Case 4: Non-listed Real Estate Investor Company}

The fourth case study was carried out in a large non-listed real estate investment company, which is the major investor in the Finnish residential market. It owns altogether more than 23000 rental apartments all over the nation that amount to 1.5 million square meters. The service provider base of the company consists of about one hundred of service providers. The objectives of the company in procurement and supply management of FM services include: decreasing a turnover rate of tenants by improving the quality of purchased services in the long run, defining a cohesive method for coordinating service providers, rationalizing the service provider base by bundling services and developing more collaborative relationships with key service providers.

In order to manage the large number of service providers, the case company has authorized sourcing decisions to regional decentralized units with approximately forty individuals. The service contracts are mainly managed internally by these individuals. It was found that the decentralized units helps the case company to utilize the buyers' local knowledge, which enables the company is to negotiate better prices with small suppliers in local markets. In addition, contact with a larger number of suppliers increases the amount of information available to the company's decision makers on local market developments. By coordinating purchasing with the small decentralized units, the case company is able to communicate more effectively with the needs of locals. However, as decentralization commits a high number of individuals to managing the service provider base, disparate procurement procedures among the individuals are likely to increase, which may in turn increase the cost of service provider base coordination. For example, the company has to cope with many different ways of repairing bidding documents.

In order to decrease the cost of coordination, the company has objectively reduced the service provider base by bundling different services regionally in multiple sites. It was found that differentiation of users in premises affects service bundling. As the needs of the users of residences are often quite homogenous, it is easier to form a bundled service package that fits all sites. For bundling services, the company has less differentiated operating procedures between the sites, which decreases the cost of managing the service provider base. On the other hand, when contracts are bundled or extended, the purchase becomes more complex and the uncertainty over whether or not one service provider is capable to succeed in all different service areas become higher. For that reason, control problems are not avoidable and thus, the case company has decided for buying especially technically demanding services separately from the small specialized service providers, without bundling. In addition, it has been difficult to extend the service package to fit all the technically demanding services into the same package since there is a lack of service providers in the Finnish FM service market that can provide such a wide range of services regionally and are able to provide services for companies that have large real estate portfolios.

While the company has rationalized the service provider base, it is also developing a partnering relationship with two property management companies, which are partly responsible for tenant relationships. The management partners are seen as a strategic asset to the case company, which gets a lot of detailed information regarding tenants from its partners. This was a clear motive for entering into closer collaboration with the managing company.

\section{ANALYSIS OF CASE STUDIES}

In this chapter the results of the empirical analysis are drawn together based on a cross case analysis of the presented cases. All the case organizations have placed emphasis on sourcing strategy formulation by reorganizing 
sourcing functions, rationalizing the service provider base and developing long term relationships with service providers. As discussed earlier, our framework specifically addresses these strategic elements. When analysing internal elements of sourcing strategy decisions, similarities can be found between the case organizations (Figure 2). To simplify these similarities, four different arrows are presented in the framework. Each of the arrows represents the main routes of the case organization's sourcing strategies. Other exceptions of the main routes are discussed in the text.

The first decision category, once the decision of providing services in-house or buying them from external market are made in favour of buy, the sourcing interfaces were analyzed by using two choices. The most common sourcing organization form to pursue was in-house sourcing (Cases 1, 2, and 4). While some of the managing tasks were outsourced to an external property managing company, it was seen as an important factor of successful service procurement and management that strategic knowledge about markets and procurement practices should be maintained inhouse (Cases 3 and 4). This external sourcing model allowed those companies to concentrate their scarce resources on a set of real estate investment activities and to focus on more strategic procurement tasks including strategic planning and steering the activities of the supply network towards the overall goals of the company.

In the second decision category, decentralized and centralized decision- making were analysed. Among the cases, most often the authority of sourcing decisions was given to the centralized sourcing unit (Cases 1, 2 and 3 ). There were several common motives for the coordination of service procurement in a centralized manner. The main motives for centralization were the realisation of economies of scale, decreasing disparate procurement procedures, and releasing resources to more important activities. Beyond this, the main reason for selecting the decentralized form was to secure easy access to a local market (Case 4). In addition, instead of coordinating the service procurement in a decentralized manner and developing individual contracts, a centralized unit is able to purchase larger quantities and offer the prospect of future purchases for the service providers. Large volumes and a rela-

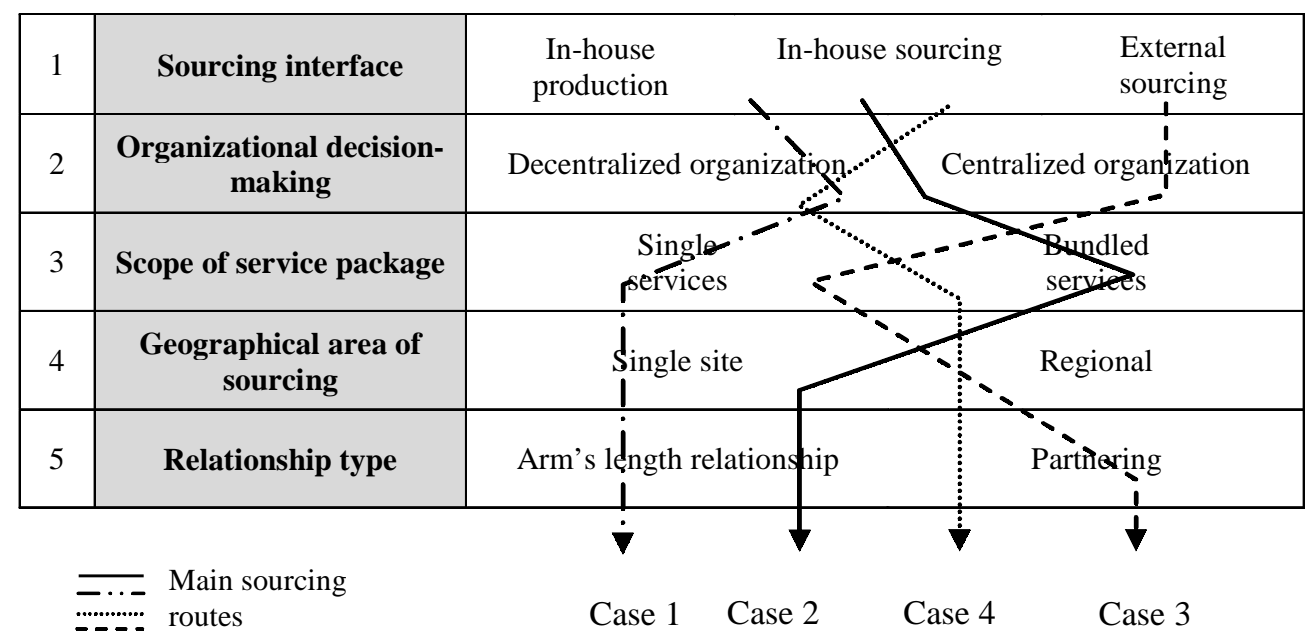

Figure 2. Main sourcing strategy routes in the case organizations 
tively small and centralized procurement organization seem to offer a better starting point for establishing collaborative relationships. It is easier to control a service provider base with few collaborative relationships than use multiple service providers with whom there is an arm's length relationship.

In the third category, the scope of service package was studied with two choices: to buy single services by a number of service contracts or bundle them to one contract. Although only two of case organizations were currently splitting purchased services to single specialised service providers without bundling (Cases 1 and 3), all the case organizations were aware of only the limited benefits that can be achieved through the service bundling; they also recognised that bundling is risky in some circumstances. It was stated that cost benefits are achieved if the service processes are planned in the way that one person can do different service tasks in one site or even several sites. In addition, once bundling services into one contract has been done, service providers are also more willing to provide services, which they do not typically provide. However, some difficulties often arise when expanding a purchased service package by bundling technical services with the non-technical ones. Firstly, the service provider may not have the required capabilities and competences for providing all bundled services in the way required. In addition, if services are bundled into packages that are too extensive, the problem arises that there are not enough service providers in Finnish FM market that can provide all needed services, especially in the case of technically demanding service packages.

In the fourth category, the defining of the geographical area of sourcing was analysed. In two of all the cases, the main route of rationalizing the service provider base was found to be the grouping of the specific services in a regional basis to one service provider (Cases 3 and 4). In the analysis of grouping of specific services regionally, it was found that the central objective of grouping sites under one con- tract is to reduce the number of direct service providers in order to cut transaction costs. The cost advantages are created if the sites are located close to each other. In this favourable situation, the service provider can convert savings into lower prices, higher service levels or the creation of innovative structures and procedures. An additional cost advantage is created if there is no need to use a large number of individuals for service procurement and management.

There are also some circumstances in which the case organizations have mainly purchased on a single site basis (Cases 1 and 2). The main reason identified for purchasing on a single site basis was that there are no service providers in the market that can provide the required services for all the sites in a large real estate portfolio. Synergy is not created if the service provider is unable to reach the number of sites from one location without using second and third tier service providers. The other reason to buy on a single site basis was that the property is a specialized property with special technical requirements based on specific demanding operations of the user (Case 3). An example of such a property is a hospital building where failures in service provision could have dramatic negative consequences. When buying more technically demanding services, the broader and complex the service package becomes, the more difficult it usually becomes to procure and manage.

When looking more closely at the grouping of sites, one of the organizations has used grouping in order to form a preferred service provider model (Case 3). This preferred sourcing strategy has many of the features of multiple sourcing, single sourcing and partnership sourcing as presented in the literature. The basic idea behind the preferred service provider structure is to achieve the best available skills and expertise in a particular service area. On the other hand, splitting the services between limited service providers reduces the supply risk for the purchased service area. Compared to single sourcing, in this situation 
the dependence on the service provider is lower and it is easier to evaluate the prices and quality levels of the current service providers. Compared to multiple sourcing, fewer resources are needed for the relationship management tasks and it is easier to control that the quality of service remains the same in different sites. The other effect of using the preferred service provider base is that it leaves more resources for procurement that is then able to develop closer relationships with the remaining service providers.

In the fifth category, selection of relationship type was studied. It was found that wide range of relationship types was mentioned. While two of the case organizations (Cases 1 and 2) were newly moving from an arm's length relationships to a collaborative approach in managing their relationships with service providers, the others were selecting partnering relationships (Cases 3 and 4). When the case organizations were planning to enter or had already entered into the closer relationships with services providers, terms operational partnering (Case 3) and partnership relations were used (Cases 1, 2 and 4). In addition, the strategic partnership was mentioned in relationships with the external property managing companies (Cases 3 and 4). In these cases, the strategic partners had wide-ranging responsibilities in managing the client's customer (i.e. tenant) relations. However, the characteristic of those "partnership type relationships" was that the client was willing to commit its service providers to a long term relationship. It is also important to note that when the purchased services are grouped into larger packages or when services are purchased for wider geographical regions, purchased packages become attractive and large enough for developing partnering relations.

When analysing the framework through the case organization as a whole, there are also some suggestions for developing the presented theoretical framework. Firstly, besides grouping sites in a regional basis, the sites can be also grouped under nation-wide contracts.
Thus, it could be valuable to add the national wide choice to the fourth category. Secondly, in the fifth category, the selection of relationship type is limited if using only two discrete decision choices. Based on the analysis there seems to exist different types of partnering in the FM context. Thus, the partnering choice could be divided in two types of partnering relationships: operational and strategic partnering. Thirdly, despite the fact that there is no empirical evidence to suggest that there should be more alternative choices for the external sourcing in the first category, it is important to understand that external sourcing can be arranged in many forms. Thus, when considering outsourcing procurement and management FM service tasks to an external management company, the risk sharing and the earning principles of different management models should be carefully analysed as a part of sourcing strategy. Lastly, it is important to note that in the framework, the decision category does not always include discrete alternative choices but more like a continuum from one choice to another or choices parallel to each other. As an example of the former, the level of collaboration with FM service partners may vary from a very short term relationship to a long term strategic partnership and as an example of the latter, one company may buy FM services both on a single site basis and a regional basis.

\section{CONCLUSIONS}

The aim of this study was to provide a holistic view and deep understanding of the phenomena of sourcing strategies in FM services. It was surprising as it is commonly suggested that effective procurement planning and management of FM services can directly affect the relative success or partial failure of an organization's business (e.g. Leifer 2003; Chotipanich 2004; Rogers 2004), the none of the studied case organizations had common sourcing strategy development programmes and lacked written forms of sourcing strategies. The studied 
strategies were rather emerged than carefully planned. Therefore, it was hard to identify any formal sourcing strategy and implementation processes in the case organizations. Based on empirical analysis it was seen that the essential elements of sourcing strategy processes that are presented in theory are not used in sourcing strategy practice in FM services. The processes of evaluation of the business environment, evaluation of potential service providers, analysis of alternative sourcing decisions and selecting a certain strategy were not systematically considered.

It was also interesting that earlier studies have been limited and have focused only on partial elements of sourcing strategies mostly without any efforts toward integration (e.g. Usher 2004; Barret and Baldry, 2003; Ancarani et al. 2004; Atkin, B. and Brooks, A., 2005; Lehtonen, 2006). However, this study points out using both theoretical and empirical evidence that in reality the different elements of sourcing strategy do not coincide with the one archetype of sourcing decisions. Instead, the realised sourcing strategies in FM services are more like an integration of the different features of these approaches. The case study provided evidence to support the conclusion that the development of sourcing strategies is influenced by number of different decisions like deciding the structure of the sourcing organization, defining the scope of service packages, defining the geographical area of sourcing and selecting a certain relationship type. In addition, the development of sourcing strategies is influenced by the availability of the service providers in the market. Thus, it is suggested that all the decisions should be evaluated against the market conditions.

This study has presented those elements of strategic sourcing decisions that are essential for the development of sourcing strategy in FM services. While companies are starting to develop sourcing strategies, the framework helps to evaluate different strategic directions and the alternative sourcing strategies in FM services. It is suggested that companies could ap- ply the presented conceptual framework as a starting point for the forming of sourcing strategies in FM services. It is also put forth that by using the framework, organisations could realize the different sourcing options to leverage their consolidated purchasing power. The sourcing strategies and more analytical development programmes are needed in order to realize sourcing objectives, select an appropriate strategy and steer procurement more towards the company's business objectives. Through effective analysis of different sourcing decisions, process standardization and supplier relationship management programs, organisations may also find other targets for organisational development. Thus, one of our suggestions is also that most organisations, at least large real estate owners, should view the development of sourcing strategies as an important phase of the procurement cycle.

Altogether, the study contributes to purchasing management literature from the FM services point of view. The results can be useful for buyer organisations in improving strategic planning of sourcing and the performance and efficiency of sourcing organisations. However, some limitations should be recognised and taken into account when interpreting our findings.

\section{LIMITATIONS AND FURTHER RESEARCH}

The results should not be freely generalized since they are not necessarily adaptable to other support services. It is important to note that the sourcing strategies may vary from one sourcing situation to another. Each sourcing situation is unique in reference to the type of purchase, the phases of the procurement cycle, the past purchasing history, the nature of the supply environment and the buying organisation itself (c.f. Corey, 1978). Thus, a certain sourcing strategy in one business environment may not be as successful when transplanted elsewhere. In addition, as the study was also carried out only in a single 
country, differences between markets could not be observed.

Beneficially, this study used replication logic in multiple organisations and concentrated on the different sectors of the property market and thus, its results may be generalized to some extent to fit the FM services sector. Compared to other models in the literature (e.g. Usher 2004; Barret and Baldry, 2003; Ancarani et al. 2004; Atkin, B. and Brooks, A., 2005; Lehtonen, 2006), our sourcing strategy framework takes into account a wide range of sourcing options and also integrates other models' specific issues of sourcing strategies together. However, the sample covers only large companies in the Finnish FM service market who participated in the research projects as corporate research partners and are active in R\&D. Therefore, the study sample may be somewhat skewed toward companies with proactive procurement management.

As this study is specific to FM services, it is important to encourage future research on strategic sourcing and purchasing management activities also in other business services. It would also be fascinating to carry out this same study in different markets in order to find out possible market-specific and culture-related differences. Furthermore, in order to improve the development of sourcing strategies in future, more exact sourcing strategy guidelines and step by step sourcing routes for different types of FM services should be made.

\section{REFERENCES}

Ancarani, A. and Capaldo, G. (2005) Supporting decision making process in facilities management services procurement: A methodological approach. In proceedings of the 14th IPSERA Conference, Archamps, March, pp. 363-374.

Ancarani, A., Capaldo, G., Pontrandolfo, P., Salaris, A. (2004) Procurement in public organisations: Choosing between integrated facility services and separated ones. In proceedings of the 13th IPSERA Conference, Catania, April, pp. 49-57.

Atkin, B. and Brooks, A. (2005) Total facilities management, Blackwell Science, Oxford, 238 p.
Barney, J. (1995) Looking inside for competitive advantage. Academy of Management Executive, 9(4), p. 49-61.

Barrett, P. and Baldry, D. (2003) Facility Management Towards Best Practice, Blackwell Science, London.

Bensaou, M. (1999) Portfolios of buyer-supplier relationships. MIT Sloan Management Review, 40(4), p. 35-44.

Bröchner, J., Olsson, H. and Sinik, D. (2004) Serviced offices: Capabilities for FM coordination. Facilities, 22(3/4), p. 74-78.

Carr, A. and Smeltzer, L. (1997) An empirical based on operational definition of strategic purchasing. European Journal of Purchasing and Supply Management, 3(4), p. 199-207.

Choi, T. Y., Dooley, K. J. and Rungtusanatham, M. (2001) Supply networks and complex adaptive systems: control versus emergence. Journal of Operations Management, 19(3), p. 351-366.

Choi, T. Y. and Hong, Y. (2002) Unveiling the structure of supply networks: case studies in Honda, Acura, and DaimlerChrystler. Journal of $\mathrm{Op}$ erations Management, 20(5), p. 469-493.

Chotipanich, S. (2004) Positioning facilities management. Facilities, 22(13/14), p. 364-372.

Corey, E. R. (1978) Procurement Management. Strategy, Organization, and Decision Making, CBI Publishing Company, Boston, 302 p.

Cousins, P. (2002) A conceptual model for managing long-term inter-organisational relationships. European Journal of Purchasing and Supply Management, 8(2), p. 71-82.

Cox, A. (1996) Relational competence and strategic procurement management. Towards an entrepreneurial and contractual theory of the company. European Journal of Purchasing and Supply Management, 2(1), p. 57-70.

de Boer, L., Holmen, E. and Pop-Sitar, C. (2003) Purchasing as an organizational design problem: the case of non-product-related items and services. Management Decision, 41(9), p. 911-922.

Eisenhardt, K. (1989) Building Theories from Case Study Research. Academy of Management Review, 14(4), p. 532-550.

Ellram L. (1993) Total cost of ownership: Elements and implementation. International Journal of Purchasing and Materials Management, 29(4), p. 3-12.

Ellram, L. and Carr, A. (1994) Strategic Purchasing: A History and Review of the Literature. 
International Journal of Purchasing and $M a$ terial Management, Spring, p. 10-18.

Farmer, D. and van Weele, A. J. (1995) (Ed.) Gower, Handbook of Purchasing Management, $581 \mathrm{p}$.

Gadde, L.-E. and Håkansson, H. (1994) The changing role of purchasing: reconsidering three strategic issues. European Journal of Purchasing and Supply Management, 1(1), p. 27-35. In Ford, D. (Ed.): Understanding Business Marketing and Purchasing, 3rd edition, Thomson Learning, London, 2002, 488 p.

Goffin, K., Szwejczewski, M. and New, C. (1997) Managing suppliers: when fewer can mean more. International Journal of Physical Distribution and Logistics Management, 27(7), p. $422-436$.

Grönroos, C. (2000) Service management and marketing: a customer relationship management approach, John Wiley and Sons Ltd, Chichester.

Gummesson, E. (1991) Qualitative methods in management research, Newbury Park: Sage.

Hines, P. (1995) Network Sourcing: A Hybrid Approach. International Journal of Purchasing and Materials Management, Spring, p. 18-24.

Hui, E. and Tsang, A. (2004) Sourcing strategies of facilities management. Journal of Quality in Maintenance Engineering, 10(2), p. 85-92.

Incognito, J. D. (2002) Outsourcing - Ensuring survival with strategic global partners. Journal of Facilities Management, 1(1), p. 7-15.

Jackson, R. W., Neidell, L. A. and Lunsford, D. A. (1995) An empirical investigation of the differences in goods and services as perceived by organisational buyers. Industrial Marketing Management, 24(2), p. 99-108.

Johnson, J. L. (1999) Strategic Integration in Industrial Distribution Channels: Managing the Interfirm Relationship as a Strategic Asset. Journal of the Academy of Marketing Science, 27(1), Winter, p. 4-18.

Kadefors, A. and Bröchner, J. (2004) Building users, owners and service providers: New relations and their effects. Facilities, 22(11-12), p. 278-283.

Koskela, T. (2005) A Method for Strategic Technical Life Cycle Management of Real Estates, Helsinki University of Technology Laboratory of Industrial Management, Doctoral dissertation series, 2005/1, Espoo, 230 p.

Kraljic, P. (1983) Purchasing must become supply management. Harvard Business Review, 61(5), p. 109-117.

Krumm, P. J., Dewulf, G. and Jonge, H. (1998) Managing key resources and capabilities: pinpointing the added value of corporate real estate management. Facilities, 16(12), p. 372-379.

Lehtonen, T. (2004) Attributes and success factors of partnering relations - A theoretical framework for facility services. Nordic Journal of Surveying and Real Estate Research, Special Series, Vol. 2, p. 31-46.

Lehtonen, T. and Salonen, A. (2006) An empirical investigation of procurement trends and partnership management in FM services - A Finnish survey. International Journal of Strategic Property Management, 10(2), p. 65-78.

Lehtonen, T. (2006) Partnering relations - justification and success factors from facilities management perspective, Dissertation (manuscript), Helsinki University of Technology, Finland.

Liefer D. (2003) Building ownership and FM. Facilities, 21(1-2), p. 38-41.

Lonsdale C. (1999) Effectively managing vertical supply relationships: a risk management model for outsourcing. Supply Chain Management-An International Journal, 4(4), p. 176-183.

Macbeth, D. K. (1994) The role of purchasing in a partnering relationship. European Journal of Purchasing and Supply Management, 1(1), p. 19-25.

Meneghetti, A. and Chinese, D. (2002) Perspectives on facilities management for industrial districts. Facilities, 20(10), p. 337-348.

Mentzer, J. T., Min, S. and Zacharia, Z. G. (2000) The nature of interfirm partnering in supply chain management. Journal of Retailing, 76(4), p. 549-568.

Min, H. and Galle, W. (1991) International Purchasing Strategies of Multinational U.S. Firms. International Journal of Purchasing and Material Management, Summer, p. 9-18.

Newman, R. (1988) Single Source Qualification. Journal of Purchasing and Materials Management, Summer, p. 10-17.

Olsen, R. F. and Ellram, L. M. (1997) A portfolio approach to supplier relationships. Industrial Marketing Management, 26(2), p. 101-113.

Parker, D. and Hartley, K. (1997) The economics of partnership sourcing versus adversarial competition: a critique. European Journal of Purchasing and Supply Management, 3(2), p. 115-125. 
Pearson, J. and Gritzmacher, K. (1990) Integrating Purchasing into Strategic Management. Long Range Planning, 23(3), p. 91-99.

Quayle, M. (1998) Industrial procurement: factors affecting sourcing decisions. European Journal of Purchasing and Supply Management, Vol. 4, p. 199-205.

Quinn, J. B. and Hilmer, F. G. (1994) Strategic outsourcing. MIT Sloan Management Review, 35(4), Summer, p. 43-55.

Ramsay, J. and Wilson, I. (1990) Sourcing/Contracting Strategy Selection. Operations and Production Management, 10(8), p. 19-28.

Roberts, P. (2001) Corporate competence in FM: Current problems and issues. Facilities, 19(7-8), p. 269-275.

Rogers, P. (2004) Performance matters: How the high performance business unit leverages facilities management effectiveness. Journal of Facilities Management, 2(4), p. 371-381.

Salonen, A., Lehtonen, T. and Ventovuori, T. (2005) A review and classification of empirical research in facilities management. In Proceedings of the 4th European Research Symposium in Facilities Management, pp. 477-485.

Smeltzer, L. (1997) Conditions That Create Influence for Purchasing in Corporate Strategic Planning, The Center for Advanced Purchasing Studies, CAPS. $88 \mathrm{p}$.

Smith, J., Zheng, B., Love, P. and Edwards, D. (2001) Procurement of construction facilities in Guangdong Province, China: factors influenc- ing the choice of procurement method. Facilities, 22(5-6), p. 141-148.

Snyder, A. and Ebeling, H. (1992) Targeting a company's real core competencies, p. 123-133, Published in Campbell, A. and Luchs, K. 1997 (ed.), Core Competency-Based Strategy, Thompson Business Press, London, $327 \mathrm{p}$.

Then, D. (2000) The role of real estate assets in supporting the fulfilment of corporate business plans: key organisational variables for an integrated resource management framework. Facilities, 6(7-8), p. 273-280.

Usher, N. (2004) Outsource or in-house facilities management: The pros and cons. Journal of Facilities Management, 2(4), p. 351-359.

Webster, F. E. Jr. (1992) The changing role of marketing in the corporation. Journal of Marketing, 56(4), p. 1-17.

Venkatesan, R. (1992) Strategic Sourcing: Make or Not to Make. Harvard Business Review, Nov.Dec., p. 98-107.

Virolainen, V.-M. (1998) Motives, Circumstances, and Success Factors in Partnership Sourcing. Research papers 71, Lappeenranta University of Technology, Finland, $232 \mathrm{p}$.

Woodside, A. and Wilson, E. (2003) Case study research methods for theory building. Journal of Business and Industrial Marketing, 18 (6-7), p. $493-508$.

Zeng, A. (2000) A synthetic study of sourcing strategies. Industrial Management \& Data Systems, 100(5), p. 219-226. 


\section{SANTRAUKA}

\section{STRATEGINĖS IŠTEKLIŲ SISTEMOS ELEMENTAI PASTATŲ ŪKIO PASLAUGOMS VALDYTI: KELIU ATVEJŲ TYRIMAS}

\section{Tomi VENTOVUORI}

Šiuo darbu siekiama nustatyti strateginès išteklių sistemos elementus sprendimų priëmimo procese ir išsiaiškinti, kokie veiksniai skatina rinktis konkrečią strateginę išteklių sistemą teikiant pastatų ūkio valdymo paslaugas. Tyrimas pagrịstas literatūros apžvalga ir kelių atvejų tyrimu, atliktu keturiose organizacijose, kurios atstovauja skirtingiems pastatų ūkio valdymo paslaugų klientų tipams. Siekiant rasti optimalią strateginę išteklių sistemą ir suprasti ịvairiu ištekliu tvarkymo variantų pasekmes, reikia išanalizuoti penkias sprendimų kategorijas: pirkimo ribas, sprendimų prièmimą dẻl pirkimo, paslaugų paketus, grupavimą ir santykių tipą. Yra ir kitų elementų, i kuriuos reikia atsižvelgti, plètojant strateginę išteklių sistemą, tokių kaip skirtingi verslo elementai apskritai ir vyraujančios rinkos sąlygos. Pabrèžtinai siūloma, kad įmonès taikytų pristatytajį integruotą metodą, kuris yra atspirties taškas plètojant strategines išteklių sistemas pastatų ūkio valdymo paslaugu srityje. Be to, strateginès išteklių sistemos kūrimą įmonès turi laikyti svarbiu pirkimų ciklo etapu. 